\title{
Analysis of the sorption properties of different soils using water vapour adsorption and potentiometric titration methods**
}

\author{
Kamil Skic*, Patrycja Boguta, and Zofia Sokołowska \\ Institute of Agrophysics, Polish Academy of Sciences, Doświadczalna 4, 20-290 Lublin, Poland
}

Received Ocotber 30, 2015; accepted May 17, 2016

\begin{abstract}
A b s t r a c t. Parameters of specific surface area as well as surface charge were used to determine and compare sorption properties of soils with different physicochemical characteristics. The gravimetric method was used to obtain water vapour isotherms and then specific surface areas, whereas surface charge was estimated from potentiometric titration curves. The specific surface area varied from 12.55 to $132.69 \mathrm{~m}^{2} \mathrm{~g}^{-1}$ for Haplic Cambisol and Mollic Gleysol soil, respectively, and generally decreased with $\mathrm{pH}$ $(\mathrm{R}=0.835 ; \alpha=0.05)$ and when bulk density $(\mathrm{R}=-0.736 ; \alpha=0.05)$ as well as ash content $(\mathrm{R}=-0.751 ; \alpha=0.05)$ increased. In the case of surface charge, the values ranged from 63.00 to $844.67 \mu \mathrm{mol} \mathrm{g}^{-1}$ Haplic Fluvisol and Mollic Gleysol, respecively. Organic matter gave significant contributions to the specific surface area and cation exchange capacity due to the large surface area and numerous surface functional groups, containing adsorption sites for water vapour molecules and for ions. The values of cation exchange capacity and specific surface area correlated linearly at the level of $\mathrm{R}=0.985 ; \alpha=0.05$.

$\mathrm{K}$ e y w o r d s: potentiometric titration, water vapour isotherms, cation exchange capacity, specific surface area
\end{abstract}

\section{INTRODUCTION}

Knowledge about soil characteristics is essential for description, interpretation, and prediction of the course of physical, chemical, and biological processes that take place in soils (Bieganowski et al., 2013). Most chemical processes occur on colloid surfaces because of their chemical cover, large surface area, as well as surface charge. Sorption is a process in which one substance takes up or holds another one and, in the case of soil, it determines soil ability to

\footnotetext{
*Corresponding author e-mail: kskic@ipan.lublin.pl

**This publication is based on studies within the framework of a research project financed from funds of the National Science Centre in accordance with decision: DEC-2013/11/D/NZ9/02545, implementation period 2014-2017.
}

retain (absorption or adsorption) ions, particle suspensions, gases, vapours, and micro-organisms. Sorption processes play a fundamental role in the maintenance of the proper soil structure, supply of plant nutrients, their migration and bioavailability (Kalembasa et al., 2011). Furthermore, it has an influence on the water flow as well as dissolution and neutralization of various pollutants that have been introduced to soil. However, an extremely complex mineral, organic, and ionic composition (clay minerals, crystalline and amorphous iron and aluminum oxides, amorphous minerals, humus as well as clay-humus complexes) causes high non-uniformity and thereby difficulty in the interpretation of the soil medium properties (Józefaciuk et al., 2006; Sokołowska, 1992). Thus, studies of surface chemistry frequently involve the analysis of water vapour adsorption and potentiometric titration curves.

The main goal of this paper was to describe sorption abilities of different types of soils by linking results from two measurements techniques. In this work, we performed experiments based on water vapour adsorption as well as on potentiometric titration. Experimentally measured adsorption isotherms were used to evaluate the specific surface area and the amount of adsorbed water vapour. Elaboration of potentiometric titration curves allowed calculation of the surface charge, the average surface dissociation constants, and the concentration of surface charge calculated as a ratio between surface charge $\left(Q_{v}\right)$ and specific surface area $\left(S_{B E T}\right)$.

(C) 2016 Institute of Agrophysics, Polish Academy of Sciences 
Finally, we tried to find statistical correlations between sorption characteristics and some physico-chemical properties of soils, eg the ash content, bulk density, $\mathrm{pH}$ as well as the organic and total carbon content.

\section{MATERIALS AND METHODS}

The study was carried out on samples taken from soil profiles at the depth of $0-20 \mathrm{~cm}$, from the Lublin region, eastern Poland. Soils were selected on the basis of their physico-chemical properties and were formed from different parent material. They represented the type of Haplic Fluvisol (soil 1), Haplic Chernozem (soil 2), Mollic Gleysol (soil 3), Rendzic Phaeozem (soil 4), Stagnic Luvisol (soil 5), and Haplic Cambisol (soil 6) (in accordance with the WG WRB 2006 classification). Soil material was dried at a temperature of $298 \mathrm{~K}$, stirred in a mortar and sieved through a sieve with a $1 \mathrm{~mm}$ mesh. Prepared soil samples were used for further laboratory tests in accordance with standard techniques and procedures. The basic physicochemical analysis included the determination of parameters, such as $\mathrm{pH}$, organic carbon $\left(C_{\text {org }}\right)$, total carbon $\left(C_{t o t}\right)$, bulk density $(\rho)$, and ash content $(A)$ (Esmaeilzadeh and Ahangar, 2014).

The water vapour sorption isotherms were obtained by the gravimetric method in accordance with the Polish standard PN-Z-19010-1. In this method, the adsorbate molecules are accumulated at the soil surface by physical interactions. During the adsorption step, relative water vapour pressures rise as a result of stepwise decreasing concentrations of sulfuric acid solutions. Soil samples reached equilibrium, at given $\mathrm{p} \mathrm{p}_{0}^{-1}$, during two days; afterwards, the amount of adsorbed molecules was measured by weighing. Adsorbed water vapour was computed as the difference between the weight of the sample with water and the dry sample (dried in an oven at $378 \pm 1.0 \mathrm{~K}$ ). The measurements were replicated three times, keeping the temperature constant at $\mathrm{T}=294 \pm 0.1 \mathrm{~K}$.

The determination of specific surface area of'suil materials was based on the application of the Brunauer, Emmet, and Teller (BET) equation. The linear form of the BET equation is presented below:

$$
\frac{x}{N(1-x)}=\frac{1}{C_{B E T} N_{m}}+\frac{\left(C_{B E T}-1\right)}{C_{B E T} N_{m}} x
$$

when: aplied to the adsorption data in the range of relative pressures $0<\mathrm{p}_{0}^{-1}>0.35, \mathrm{x}=\mathrm{p} \mathrm{p}_{0}^{-1}$ allows obtaining the monolayer capacity $\left(N_{m}\right)$. In the above equation, $N$ is the amount of adsorbed water vapour and $C_{B E T}$ is a constant related to the energy of surface interactions. Next, by multiplying the amount of gas adsorbed in a monolayer by the area occupied by its single molecule, the overall amount of the soil surface can be estimated from the equation:

$$
S=N_{m} M^{-1} \mathrm{~L} \sigma,
$$

where: $\mathrm{L}$ is the Avogadro number $\left(6.02310^{-23}\right.$ molecules per mole), $M$ is the molecular weight of gas or vapour (gram per mole), and $\sigma$ is the molecule cross-sectional area for gas or vapour (10.508 $10^{-20} \mathrm{~m}^{2}$ for the water molecule).

The automatic titrations were performed in triplicate using a Titrino 702 SM autotitration unit provided by Metrohm. According to the procedure, $0.3 \mathrm{~g}$ soil samples were placed into a $40 \mathrm{ml}$ plastic beaker, modified by adding $20 \mathrm{ml}$ of $1 \mathrm{M} \mathrm{NaCl}$ solution, and left for $24 \mathrm{~h}$. Then, the suspensions were adjusted to $\mathrm{pH} 2.98$ with a small portion of $\mathrm{HCl}$ until $\mathrm{pH}$ was equilibrated. When the $\mathrm{pH}$ did not change more than by 0.01 unit, the suspensions were back titrated with a $0.1 \mathrm{~mol} \mathrm{dm}^{-3}$ solution of $\mathrm{NaOH}$ prepared on the basis of $1 \mathrm{M} \mathrm{NaCl}$. The titrant volume was recorded every 0.01 unit of $\mathrm{pH}$ in the range of $3<\mathrm{pH}>10$. A reference titration curve was performed for the equilibrium solution of $1 \mathrm{M}$ $\mathrm{NaCl}$ following the procedure described above.

The hydroxyl ions added neutralize protons of soil surface functional groups of an acid nature. Therefore, an increase in the negative surface charge is observed. The curves obtained can be considered as the image of surface charge changes occurring in the solid phase $\Delta Q_{v}$, in relation to $\mathrm{pH}$ :

$$
\Delta Q_{v}=N_{\text {sus }}-N_{\text {sol }},
$$

where: $N_{\text {sus }}$ is the amount of base consumed during titration of the soil suspension, $N_{\text {sol }}$ is the number of moles of base consumed during titration of the equilibrium solution (Józefaciuk and Shin, 1996; and Matyka-Szarzyńska and Sokołowska, 2005).

Fractions of surface functional groups versus the apparent surface dissociation constant, $p K_{a p p}$, were determined assuming that the surface activity of protons is equal to their activity in the solution, and that the total number of functional groups corresponds to the maximum growth of variable charge:

$f_{i}\left(p K_{a p p, i}\right)=1 / Q_{\max }\left[\Delta S O^{-}\left(\mathrm{pH}_{i+1}\right)-\Delta S O^{-}\left(\mathrm{pH}_{i}\right) /\left(p K_{a p p, i+1}-p K_{a p p, i}\right)\right.$,

where: $p K_{a p p, i}=\mathrm{pH}, Q_{\max }$ means the maximum increase in the surface charge, and $\mathrm{SO}^{-}$is the amount of surface charge that comes from dissociation of surface functional groups at given $\mathrm{pH}$.

The average value of $p K_{a p p}\left(p K_{a p p, a v}\right)$, was calculated as:

$$
p K_{a p p, a v}=\sum_{i=1}^{n} p K_{a p p, i} f_{i}\left(p K_{a p p}\right) .
$$

The cation exchange capacity $(C E C)$ was measured as the number of moles of base consumed during titration to $\mathrm{pH}=7$. The concentration of surface charge $(S C D)$ was calculated as a ratio between $Q_{v}$ and $S_{B E T}$. 
Statistical analysis was performed using Statistica 10.0 (StatSoft, Inc., Tulsa, USA). Basic statistics and Pearson correlation coefficients between selected parameters were determined. The significance level was evaluated at $\alpha=0.05$.

\section{RESULTS AND DISCUSSION}

The basic properties of the studied soils are collected in Table 1. The Table also contains surface and charge characteristics estimated from the isotherms and potentiometric titration curves, respectively.

The $\mathrm{pH}$ values of samples measured in $\mathrm{H}_{2} \mathrm{O}$ ranged from $4.45(0.00)$ to $8.00( \pm 0.01)$, while those measured in $\mathrm{KCl}$ ranged from $3.57( \pm 0.00)$ to $7.89( \pm 0.00)$. Soils 1,2 , and 5 were characterized by strong and slightly acidic $\mathrm{pH}$. Very acidic $\mathrm{pH}$ was observed for soil 6 , which was formed from acidic parent rocks poor in bases. Larger differences between the $\mathrm{pH}$ values measured in water and potassium chloride may suggest a lower abundance of minerals in this material. On the other hand, soil 3 and 4 had alkaline $\mathrm{pH}$, which indicated the presence of alkali cations in the soil solution as well as its carbonate forms. The high concentration of calcium ions is accompanied with sorption of dissolved organic matter based on mechanisms of ion and ligand exchange, hydrophobic interactions, and crosslinking bonds formation (Chantigny, 2003; Karavanova, 2013). On the other hand, $\mathrm{K}^{+}$and $\mathrm{Na}^{+}$ions may increase organic matter solubility and lead to expansion of its molecules (Marschaner and Kalbitz, 2003). The organic carbon content changed in a wide range from $0.22 \%( \pm 0.00)$ to $3.48 \%( \pm 0.14)$, whereas the total carbon content oscillated from $11.91( \pm 0.63)$ to $219.70( \pm 17.15) \mathrm{mg} \mathrm{g}^{-1}$. The smallest total and organic carbon content was measured for soil 1 . The poor contribution of humus was caused in this case by periodically occurring processes of flooding, drainage, and aeration. The highest values of $C_{\text {tot }}$ and $C_{\text {org }}$ were noticed for soil 3, for which accumulation of organic matter proceeded in high humidity in mineral parent rocks rich in calcium

T a b l e 1. Physicochemical parameters of the investigated materials including basic properties as well as parameters estimated from water vapour adsorption isotherms and potentiometric titration curves data. Standard deviations are given in parentheses. Abbreviations: $\rho$ - bulk density, $C_{\text {tot }}$ - total carbon content, $C_{\text {org }}$ - organic carbon content, $A$ - ash content, $N_{0.964}-$ average amount of water vapour adsorbed in $\mathrm{p} \mathrm{p}_{0}^{-1}=0.964, S_{B E T}$-average specific surface area, $N_{m}$ - monolayer capacity, $C E C(\mathrm{pH} 7)-$ average cation exchange capacity calculated in $\mathrm{pH} 7, Q_{v}(\mathrm{pH} 10)$ - average total variable surface charge calculated in $\mathrm{pH} 10, p K_{a p p, a v}$ - average surface dissociation constant, $S C D$ - concentration of surface charge

\begin{tabular}{|c|c|c|c|c|c|c|c|c|c|c|c|c|}
\hline$\rho$ & $C_{t o t}$ & $C_{\text {org }}$ & \multicolumn{2}{|c|}{$\mathrm{pH}$} & $A$ & $N_{0.965}$ & $S_{B E T}$ & $N_{m}$ & $C E C$ & $Q_{v}$ & $p K_{a p p, a v}$ & $S C D$ \\
\hline$\left(\mathrm{g} \mathrm{cm}^{-3}\right)$ & $\left(\mathrm{mg} \mathrm{g}^{-1}\right)$ & $(\%)$ & $\mathrm{H}_{2} \mathrm{O}$ & $\mathrm{KCl}$ & $(\%)$ & $\left(\mathrm{mg} \mathrm{g}^{-1}\right)$ & $\left(\mathrm{m}^{2} \mathrm{~g}^{-1}\right)$ & $\left(\mathrm{mg} \mathrm{g}^{-1}\right)$ & \multicolumn{2}{|c|}{$\left(\mu \mathrm{mol} \mathrm{g} \mathrm{g}^{-1}\right)$} & & $\left(\mathrm{C} \mathrm{m}^{-2}\right)$ \\
\hline \multicolumn{13}{|c|}{ Haplic Fluvisol (soil 1) } \\
\hline $\begin{array}{c}2.61 \\
(0.03)\end{array}$ & $\begin{array}{l}11.91 \\
(0.63)\end{array}$ & $\begin{array}{c}0.22 \\
(0.00)\end{array}$ & $\begin{array}{c}6.56 \\
(0.04)\end{array}$ & $\begin{array}{c}5.89 \\
(0.14)\end{array}$ & $\begin{array}{l}96.22 \\
(0.12)\end{array}$ & $\begin{array}{l}31.62 \\
(0.42)\end{array}$ & $\begin{array}{l}27.08 \\
(0.32)\end{array}$ & $\begin{array}{c}7.49 \\
(0.09)\end{array}$ & $\begin{array}{l}25.05 \\
(2.75)\end{array}$ & $\begin{array}{l}63.00 \\
(0.29)\end{array}$ & $\begin{array}{c}7.05 \\
(0.29)\end{array}$ & 2.33 \\
\hline \multicolumn{13}{|c|}{ Haplic Chernozem (soil 2) } \\
\hline $\begin{array}{c}2.61 \\
(0.02)\end{array}$ & $\begin{array}{l}17.27 \\
(0.32)\end{array}$ & $\begin{array}{c}0.50 \\
(0.02)\end{array}$ & $\begin{array}{c}5.06 \\
(0.03)\end{array}$ & $\begin{array}{c}4.32 \\
(0.02)\end{array}$ & $\begin{array}{l}95.50 \\
(0.13)\end{array}$ & $\begin{array}{l}39.13 \\
(0.30)\end{array}$ & $\begin{array}{l}31.77 \\
(0.57)\end{array}$ & $\begin{array}{c}8.79 \\
(0.16)\end{array}$ & $\begin{array}{l}69.34 \\
(0.40)\end{array}$ & $\begin{array}{l}176.96 \\
(1.09)\end{array}$ & $\begin{array}{c}7.02 \\
(0.02)\end{array}$ & 5.54 \\
\hline \multicolumn{13}{|c|}{ Mollic Gleysol (soil 3) } \\
\hline $\begin{array}{c}2.09 \\
(0.01)\end{array}$ & $\begin{array}{l}219.70 \\
(17.15)\end{array}$ & $\begin{array}{c}3.48 \\
(0.14)\end{array}$ & $\begin{array}{c}7.88 \\
(0.01)\end{array}$ & $\begin{array}{c}7.89 \\
(0.00)\end{array}$ & $\begin{array}{l}64.78 \\
(0.40)\end{array}$ & $\begin{array}{l}175.27 \\
(1.82)\end{array}$ & $\begin{array}{l}132.69 \\
(1.45)\end{array}$ & $\begin{array}{l}36.72 \\
(0.40)\end{array}$ & $\begin{array}{l}463.37 \\
(16.66)\end{array}$ & $\begin{array}{l}844.67 \\
(33.68)\end{array}$ & $\begin{array}{c}6.64 \\
(0.01)\end{array}$ & 6.37 \\
\hline \multicolumn{13}{|c|}{ Rendzic Phaeozem (soil 4) } \\
\hline $\begin{array}{c}2.56 \\
(0.00)\end{array}$ & $\begin{array}{l}39.68 \\
(0.36)\end{array}$ & $\begin{array}{c}0.38 \\
(0.03)\end{array}$ & $\begin{array}{c}8.00 \\
(0.01)\end{array}$ & $\begin{array}{c}7.83 \\
(0.02)\end{array}$ & $\begin{array}{l}93.87 \\
(0.23)\end{array}$ & $\begin{array}{c}110.09 \\
(0.93)\end{array}$ & $\begin{array}{l}84.60 \\
(0.27)\end{array}$ & $\begin{array}{l}23.41 \\
(0.07)\end{array}$ & $\begin{array}{l}279.63 \\
(14.20)\end{array}$ & $\begin{array}{l}467.44 \\
(26.27)\end{array}$ & $\begin{array}{c}6.21 \\
(0.00)\end{array}$ & 5.53 \\
\hline \multicolumn{13}{|c|}{ Stagnic Luvisol (soil 5) } \\
\hline $\begin{array}{c}2.55 \\
(0.01)\end{array}$ & $\begin{array}{l}27.25 \\
(1.14)\end{array}$ & $\begin{array}{c}0.29 \\
(0.00)\end{array}$ & $\begin{array}{c}5.94 \\
(0.01)\end{array}$ & $\begin{array}{c}5.28 \\
(0.01)\end{array}$ & $\begin{array}{l}93.29 \\
(0.26)\end{array}$ & $\begin{array}{l}40.78 \\
(0.94)\end{array}$ & $\begin{array}{l}30.53 \\
(0.72)\end{array}$ & $\begin{array}{c}8.45 \\
(0.20)\end{array}$ & $\begin{array}{l}39.37 \\
(3.44)\end{array}$ & $\begin{array}{l}123.75 \\
(4.41)\end{array}$ & $\begin{array}{c}7.41 \\
(0.14)\end{array}$ & 4.05 \\
\hline \multicolumn{13}{|c|}{ Haplic Cambisol (soil 6) } \\
\hline $\begin{array}{c}2.57 \\
(0.02)\end{array}$ & $\begin{array}{l}114.02 \\
(3.98)\end{array}$ & $\begin{array}{c}0.46 \\
(0.00)\end{array}$ & $\begin{array}{c}4.45 \\
(0.00)\end{array}$ & $\begin{array}{c}3.57 \\
(0.00)\end{array}$ & $\begin{array}{l}95.68 \\
(0.15)\end{array}$ & $\begin{array}{l}15.37 \\
(1.31)\end{array}$ & $\begin{array}{c}12.55 \\
(1.18)\end{array}$ & $\begin{array}{c}3.47 \\
(0.33)\end{array}$ & $\begin{array}{l}30.27 \\
(0.94)\end{array}$ & $\begin{array}{l}90.11 \\
(7.44)\end{array}$ & $\begin{array}{c}7.41 \\
(0.16)\end{array}$ & 7.18 \\
\hline
\end{tabular}


T a b 1 e 2. Correlation between selected parameters at $\alpha=0.05$. Abbreviations: $\rho$ - bulk density, $C_{\text {tot }}-$ total carbon content, $C_{\text {org }}-$ organic carbon content, $A$ - ash content, $N_{0.964}$ - average amount of water vapour adsorbed in p p ${ }_{0}^{-1}=0.964, S_{B E T}-$ average specific surface area, $C E C(\mathrm{pH} 7)$ - average cation exchange capacity calculated in $\mathrm{pH} 7, Q_{v}(\mathrm{pH} 10)$ - average total variable surface charge calculated in $\mathrm{pH} 10$. Bold numbers: statistical significance at $\alpha=0.05$

\begin{tabular}{ccccccccccc}
\hline Parameter & $\rho$ & $C_{\text {tot }}$ & $C_{\text {org }}$ & $\mathrm{pH} \mathrm{H}_{2} \mathrm{O}$ & $\mathrm{pH} \mathrm{KCl}$ & $A$ & $N_{0.965}$ & $S_{B E T}$ & $C E C$ & $Q_{v}$ \\
\hline$\rho$ & 1.000 & & & & & & & & & \\
$C_{\text {tot }}$ & $\mathbf{- 0 . 8 3 7}$ & 1.000 & & & & & & & & \\
$C_{\text {org }}$ & $\mathbf{- 0 . 9 6 7}$ & $\mathbf{0 . 8 2 8}$ & 1.000 & & & & & & & \\
$\mathrm{pH} \mathrm{H} \mathrm{H}_{2} \mathrm{O}$ & -0.394 & 0.013 & 0.285 & 1.000 & & & & & & \\
$\mathrm{pH} \mathrm{KCl}$ & -0.434 & 0.058 & 0.329 & $\mathbf{0 . 9 9 7}$ & 1.000 & & & & & \\
$A$ & $\mathbf{0 . 9 8 6}$ & $\mathbf{- 0 . 7 8 0}$ & $\mathbf{- 0 . 9 7 9}$ & -0.414 & -0.453 & 1.000 & & & & \\
$N_{0.965}$ & $\mathbf{- 0 . 7 3 8}$ & 0.430 & $\mathbf{0 . 6 8 2}$ & $\mathbf{0 . 8 3 1}$ & $\mathbf{0 . 8 6 4}$ & $\mathbf{- 0 . 7 5 1}$ & 1.000 & & & \\
$S_{B E T}$ & $\mathbf{- 0 . 7 3 6}$ & 0.424 & $\mathbf{0 . 6 8 5}$ & $\mathbf{0 . 8 3 5}$ & $\mathbf{0 . 8 6 8}$ & $\mathbf{- 0 . 7 5 1}$ & $\mathbf{0 . 9 9 9}$ & 1.000 & & \\
$C E C$ & $\mathbf{- 0 . 7 4 9}$ & $\mathbf{0 . 5 1 4}$ & $\mathbf{0 . 7 0 5}$ & $\mathbf{0 . 7 6 4}$ & $\mathbf{0 . 8 0 4}$ & $\mathbf{- 0 . 7 4 8}$ & $\mathbf{0 . 9 8 6}$ & $\mathbf{0 . 9 8 5}$ & 1.000 & \\
$Q_{v}$ & $\mathbf{- 0 . 7 9 8}$ & $\mathbf{0 . 5 5 8}$ & $\mathbf{0 . 7 6 5}$ & $\mathbf{0 . 7 1 4}$ & $\mathbf{0 . 7 5 8}$ & $\mathbf{- 0 . 8 0 3}$ & $\mathbf{0 . 9 8 1}$ & $\mathbf{0 . 9 7 9}$ & $\mathbf{0 . 9 9 4}$ & 1.000 \\
\hline
\end{tabular}

carbonate. The highest content of organic matter in this soil was reflected in the lowest bulk density and ash content. These parameters were $2.09 \mathrm{~g} \mathrm{~cm}^{-3}( \pm 0.01)$ and $64.78 \%$ $( \pm 0.40)$, respectively. Except soil 3, the ash content ranged from $93.29( \pm 0.26)$ to $96.22 \%( \pm 0.12)$, while bulk density was between $2.55( \pm 0.01)$ and $2.61 \mathrm{~g} \mathrm{~cm}^{-3}( \pm 0.03)$.

Table 2 shows statistical correlations between the basic parameters of the samples discussed above. Organic carbon accumulated in the studied soils was negatively correlated with the bulk density $(\mathrm{R}=0.967, \alpha=0.05)$ and the ash content $(\mathrm{R}=0.979, \alpha=0.05)$, and not correlated with their $\mathrm{pH}(\mathrm{R}=0.013, \alpha=0.05)$. It is commonly known that $\mathrm{pH}$ has a major influence on the amount of organic matter present in the soil. According to literature, an increase in $\mathrm{pH}$ leads to an increase in organic matter solubility, while soil acidification can have either a positive or negative effect (Andersson et al., 2000). However, the content of soil organic matter depends on the balance between many environmental processes and factors that could be the cause of the low dependence between $C_{\text {org }}$ and $\mathrm{pH}$ in this study.

For all tested samples, the adsorption-desorption isotherms of water vapour belonged to the second type and had the shape typical of the physical adsorption process (Fig. 1) (Brunauer et al., 1938). The isotherms were characterized by occurrence of small inflection at low values of relative water vapour pressure $\left(\mathrm{p} \mathrm{p}_{0}^{-1}=0.1\right)$, more or less steep in the central part ( $\mathrm{p} \mathrm{p}_{0}^{-1}$ from 0.1 to 0.8 ), and a rapid increase in the quantity of adsorbed water vapour from $\mathrm{p} \mathrm{p}_{0}{ }^{-1}=0.8$. Determination coefficients $\mathrm{R}^{2}$, obtained in the range where the multilayer is formed $\left(0-0.35 \mathrm{p} \mathrm{p}_{0}^{-1}\right)$, were higher than 0.99 , reflecting that the BET equation described the experimental data well.

Adsorbed molecules interacted with the soil particles to a varied extent. The amount of adsorbed water vapour for $\mathrm{p} \mathrm{p}_{0}^{-1}=0.965$ corresponds to the soil water potential of $\mathrm{pF}=4.7$. Expressed in $\mathrm{mg} \mathrm{g}^{-1}$ of the adsorbent, it ranged from $15.37( \pm 1.31)$ to $175.27( \pm 1.82)$ for soil 6 and 3 , respectively. A similar level of adsorption was observed for soil $2(39.13 \pm 0.30)$ and $5(40.78 \pm 0.94)$. The parameters of monolayer capacity $\left(N_{m}\right)$ and the specific surface area $\left(S_{B E T}\right)$ were estimated from adsorption data in the range of $\mathrm{p} \mathrm{p}_{0}^{-1}$ from 0 to 0.35 . Similar monolayer capacity from $7.49 \mathrm{mg} \mathrm{g}^{-1}( \pm 0.09)$ to $8.79 \mathrm{mg} \mathrm{g}^{-1}( \pm 0.16)$ was observed for soil 1, 2, and 5, while $N_{m}$ for soil 3 was more than 4 times higher $\left(36.72 \mathrm{mg} \mathrm{g}^{-1} \pm 0.40\right)$. Soil 6 was characterized by the smallest value of monolayer capacity, equal to $3.47 \mathrm{mg} \mathrm{g}^{-1}( \pm 0.33)$. The specific surface area ranged from $12.55( \pm 1.18)$ to $132.69 \mathrm{~m}^{2} \mathrm{~g}^{-1}( \pm 1.45)$ and decreased as follows: soil $3>4>2>5>1>6$.

It is worth mentioning that water vapour belongs to polar adsorbates and may form strong hydrogen bonds with the polar surface functional groups (Sokołowska et al., 2004). The high sorption in the case of soil 3 was probably caused by the presence of organic matter, which contains functional groups of a polar nature (mainly hydroxyls,

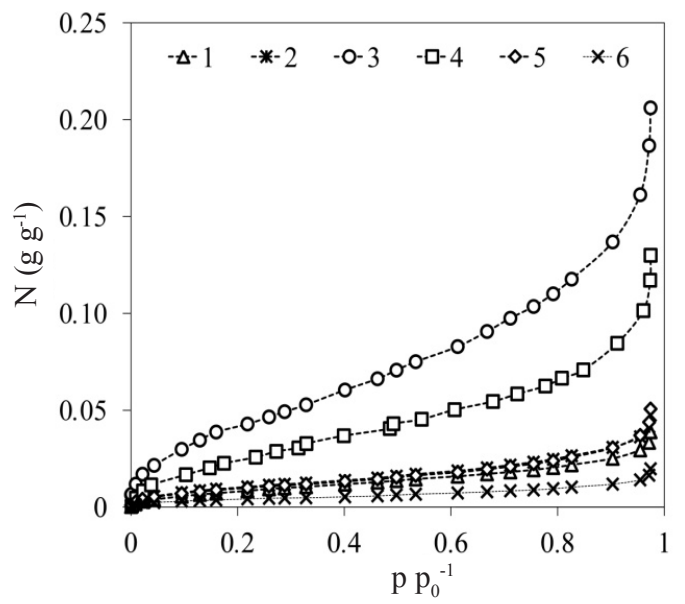

Fig. 1. Water vapour adsorption isotherms obtained for the studied soils. Abbreviations: 1 - Haplic Fluvisol, 2 - Haplic Chernozem, 3 - Mollic Gleysol, 4 - Rendzic Phaeozem, 5 - Stagnic Luvisol, 6 - Haplic Cambisol. 


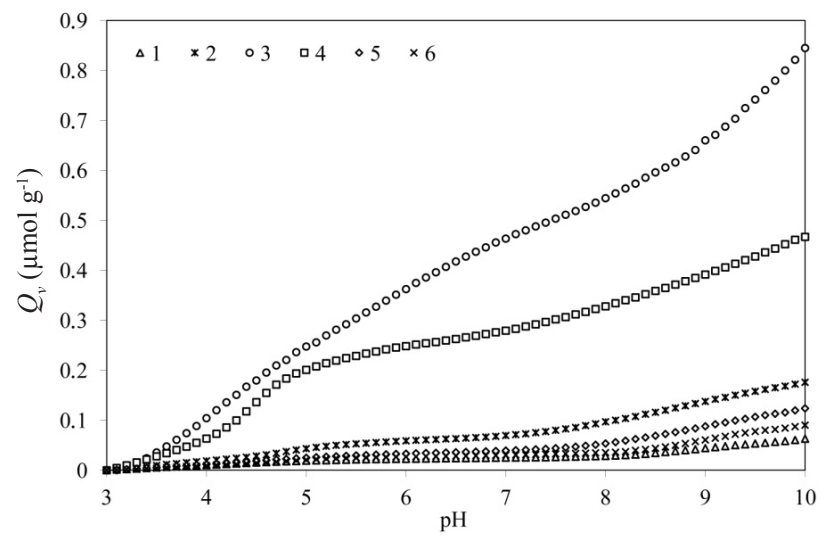

Fig. 2. Distribution of surface charge calculated from the titration curves for the studied soil materials. Explanations as in Fig. 1.

phenolics, and carboxyls). These groups together with silicates, oxides, hydrated cations as well as electric charge form adsorption centres for water vapour molecules. On the other hand, the variability of the specific surface area can also be partly explained by the differences in the type of the clay minerals with respect to the proportion of minerals to the total weight (Petersen et al., 1996). In soils rich in clay minerals, the increase in the surface area can be a result of amorphous silica formation with strong adsorption properties. A higher surface area is exhibited by soils rich in swelling clays such as montmorillonite with specific surface areas up to $810 \mathrm{~m}^{2} \mathrm{~g}^{-1}$. Non-expanding clays such as kaolinite typically have a specific surface area ranging from 10 to $40 \mathrm{~m}^{2} \mathrm{~g}^{-1}$ (Yukselen-Aksoy et al., 2010).

The variable surface charge of the soil solid phase as a function of $\mathrm{pH}$ is presented in Fig. 2. The curves differed in their course and in values of the total variable surface charge measured at $\mathrm{pH}=10$. The titration curves for soil 3 and 4 were placed much higher than these for the other soils. Their $Q_{v}$ were $844.67 \mu \mathrm{mol} \mathrm{g}^{-1}( \pm 33.68)$ and 467.44 $\mu \mathrm{mol} \mathrm{g}{ }^{-1}( \pm 26.27)$, respectively (Table 1$)$. Moreover, soils 3 and 4 were characterized by high density of variable surface charge (6.57 and $5.53 \mathrm{C} \mathrm{m}^{-2}$ ). Including all soils, $S C D$ ranged from 2.33 to $7.18 \mathrm{C} \mathrm{m}^{2}$. However, the greatest value was noticed for Haplic Cambisol for which relatively high surface charge $\left(90.11 \mu \mathrm{mol} \mathrm{g}{ }^{-1} \pm 7.44\right)$ occurred in a very small surface $\left(12.55 \mathrm{~m}^{2} \mathrm{~g}^{-1} \pm 1.18\right)$. The high surface charge and concentration of functional groups suggested high sorption abilities of samples 3 and 4 in relation to the other studied soils.

The amount of variable charge depended strongly on the $\mathrm{pH}$ of the soil solution ( $\mathrm{R}=0.764, \alpha=0.05$ ) (Table 2). Changes in $\mathrm{pH}$ can affect the charge of soil by adsorption or desorption of exchangeable cations, modification of clay mineral structure, and changes in the magnitude of variable surface charge (Józefaciuk et al., 2002). In general, a decrease in soil surface variable charge with a $\mathrm{pH}$ decrease and its increase when $\mathrm{pH}$ increases are observed.

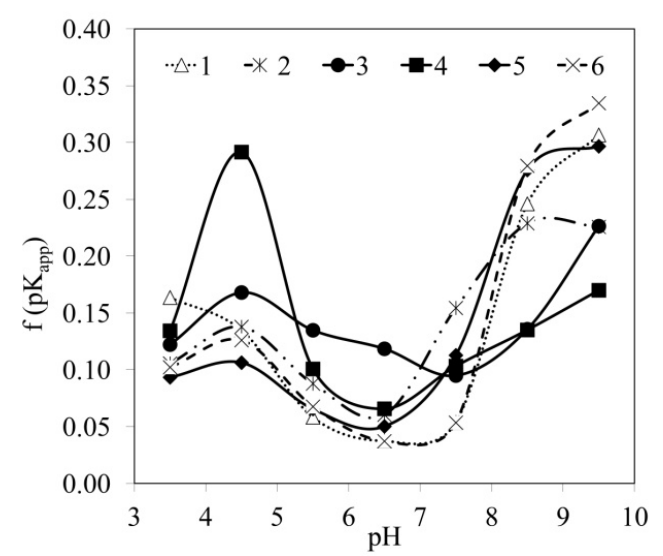

Fig. 3. Apparent surface dissociation constant distribution functions. Explanations as in Fig. 1.

The surface charge present in the low range of $\mathrm{pH}$ derived from the strongly acidic surface functional groups, in contrast to the surface charge occurring in the higher $\mathrm{pH}$ range. The relative fractions of these groups $f\left(p K_{a p p}\right)$ are presented in Fig. 3 as a function of the distribution of the apparent surface dissociation constants.

These functions are close to the parabola shape with a characteristic minimum at $p K_{a p p}$ about 6.5. Dominant surface functional groups are those for which the apparent dissociation constant is about 4.5 and 8-9. Soil 4 had a majority of groups with a strongly acidic nature, while soils 5,6 , and 1 were characterized by numerous groups with weak acidity. Carboxyl groups are strongly acidic. In contrast to this, phenol and hydroxyl groups are characterized by low acidity. This is also shown as an average of apparent surface dissociation constants of functional groups which were equal to $6.21( \pm 0.00)$ and $6.64( \pm 0.01)$ for soil 4 and 3 , respectively, and $7.41( \pm 0.14, \pm 0.16)$ in the case of soil 5 and 6 .

Soils of the temperate zone are sorbents the vast majority of which attract cations. Only a small part of the surface functional groups with a positive charge may attract anions. Therefore, we assumed that the variable surface charge obtained at $\mathrm{pH} 7$ approximately corresponds to the cation exchange capacity. $C E C$ varies depending on the soil. The greatest values were obtained for soil 3 (463.37 $\left.\mu \mathrm{mol} \mathrm{g} \mathrm{g}^{-1} \pm 16.66\right)$ and soil 4 (279.63 $\mu \mathrm{mol} \mathrm{\textrm {g } ^ { - 1 }}$ $\pm 14.20)$, and the lowest for soil $1\left(25.05 \mu \mathrm{mol} \mathrm{g} \mathrm{g}^{-1}\right.$ $\pm 2.75)$ and soil $6\left(30.27 \mu \mathrm{mol} \mathrm{g}^{-1} \pm 0.94\right)$. The lower cation exchange capacity was presumably related to the low content of organic carbon compounds like humus substances (soil 1) or the small amount of soil colloids and, as in the case of soil 6 , lower $\mathrm{pH}$. This substantially affected soil structure and ion adsorption, mainly monovalent ions (eg $\mathrm{K}^{+}$or $\mathrm{Na}^{+}$). At lower $\mathrm{pH}$ values, the amount of protonated acidic groups increased and led to neutralization of negative charge on colloids and reduction of cation exchange capacity (Esmaeilzadeh and Ahangar, 2014). 
The statistical analysis revealed that the cation exchange capacity was positively correlated with the organic and total carbon content $(\mathrm{R}=0.705, \mathrm{R}=0.514, \alpha=0.05), \mathrm{pH}$ $(\mathrm{R}=0.764, \alpha=0.05)$ as well as with the specific surface area $(\mathrm{R}=0.985, \alpha=0.05)$ (Table 2). Organic matter had a significant effect on $C E C$ due to the high $S_{B E T}$, and thus the number of active sites which can be substituted by cations (Ersahin et al., 2006). It is, therefore, clear why the specific surface area strongly correlated with the cation exchange capacity. The high linear positive correlation observed for the parameters of $C E C$ and $N_{0.965}(\mathrm{R}=0.986$, $\alpha=0.05$ ) may indicate the hydration process of exchangeable cations and its role in binding of adsorbate molecules by the colloidal fraction (Chiou and Rutherford, 1997; Dontsova et al., 2004).

\section{CONCLUSIONS}

1. The analysis with application of measurements of water vapour isotherms as well as potentiometric titration curves proved to be a reliable indicator of soil sorption properties and can be used for comparative purposes. The results revealed that Mollic Gleysol and Rendzic Phaeozem soils had greater sorption capacity than Haplic Fluvisol and Haplic Cambisol.

2. The surfaces of Mollic Gleysol and Rendzic Phaeozem contained more acidic functional groups than Haplic Fluvisol, Haplic Chernozem and especially Stagnic Luvisol and Haplic Cambisol. The distribution of surface dissociation constants and their averages showed the presence of two main types of groups, which highly contributed to the surface charge. Strong acidic functional groups that dissociate at $\mathrm{pH} 4-5$ were typical of carboxyl groups, whereas weakly acidic functional groups that dissociate at higher $\mathrm{pH}$ characterized enol and phenol groups.

3. The statistical analysis revealed that the specific surface area parameter was strongly and positively correlated with cation exchange capacity and total variable surface charge. In addition, the parameters obtained by means of water vapour adsorption correlated strongly and positively with organic carbon content and $\mathrm{pH}$, while a negative correlation was observed in the case of bulk density and ash content. The high correlation coefficients between the organic carbon, specific surface area and cation exchange capacity parameters suggest that the surface of soil organic matter contains numerous functional groups with adsorption sites for water vapour molecules and ions.

Conflict of interest: The Authors do not declare conflict of interest.

\section{REFERENCES}

Andersson S., Nilsson S.I., and Saetre P., 2000. Leaching of dissolved organic carbon (DOC) and dissolved organic nitrogen (DON) in mor humus as affected by temperature and $\mathrm{pH}$. Soil Biol. Chemistry, 32, 1-10.
Bieganowski A., Witkowska-Walczak B., Gliński J., Sokołowska Z., Sławiński C., Brzezińska M., and Włodarczyk T., 2013. Database of Polish arable mineral soils: a review. Int. Agrophys., 27, 335-350.

Brunauer S., Emmet P.H., and Teller E., 1938. Adsorption of gases in multimolecular layers. J. Am. Chem. Soc., 60, 309-319.

Chantigny M.H., 2003. Dissolved and water-extractable organic matter in soils: a review on the influence of land use and management practices. Geoderma, 113, 357-380.

Chiou C.T. and Rutherford D.W., 1997. Effects of exchangeable cation and layer charge on sorption of water and EGME vapors on montmorillonite clay. Clays Clay Miner., 45, 867-880.

Dontsova K.M., Norton L.D., Johnston C.T., and Bigham J.M., 2004. Influence of exchangeable cations on water adsorption by soil clays. Soil Sci. Soc. Am. J., 68, 1218-1227.

Erashin S., Gunal H., Kutlu T., Yetgin B., and Coban S., 2006. Estimating specific surface area and cation exchange capacity in soils using fractal dimension of particle-size distribution. Geoderma, 136, 588-597.

Esmaeilzadeh J. and Ahangar A.G., 2014. Influence of soil organic matter content on soil physical, chemical and biological properties. IJPAES, 4, 244-252.

Józefaciuk G., Muranyi A., and Alekseeva T., 2002. Effect of extreme acid and alkali treatment on soil variable charge. Geoderma, 109, 225-243.

Józefaciuk G. and Shin J.S., 1996. Water vapor adsorption on soils: II. Estimation of adsorption energy distributions using local BET and Aranovich isotherms. Korean J. Soil Sci. Fertilizer, 29/3, 218-225.

Józefaciuk G., Toth T., and Szendrei G., 2006. Surface and micropore properties of saline soil profiles. Geoderma, 135, 1-15.

Kalembasa D., Pakuła K., and Jaremko D., 2011. Sorption properties of soils in the Siedlce upland (in Polish). Acta Agrophysica, 18(2), 311-319.

Karavanova E.I., 2013. Dissolved organic matter: Fractional composition and sorbability by the soil solid phase (review of literature). Eurasian Soil Sci., 46, 833-844.

Marschner B. and Kalbitz K., 2003. Controls of bioavailability and biodegradability of dissolved organic matter in soils. Geoderma, 113, 211-235.

Matyka-Sarzyńska D. and Sokołowska Z., 2005. Physicochemical properties of mucks at different stage of secondary transformations (in Polish). Acta Agrophysica, 123, 1-68.

Petersen L.W., Moldrup P., Jacobsen O.H., and Rolston D.E., 1996. Relation between specific surface area and soil physical and chemical properties. Soil Sci., 161, 9-21.

PN-Z-19010-1, 1997. Soil quality. Determination of the specific surface area of soils by water sorption. Polish Norms, Warsaw, Poland.

Sokolowska Z., 1992. On the role of energetic and geometric heterogeneity in sorption of water vapour by soils. Application of the fractal approach. Geoderma, 45, 251-265.

Sokołowska Z., Matyka-Sarzyńska D., and Bowanko G., 2004. Specific surface area of Lublin Polesie mucks determined from water vapour and nitrogen adsorption data. Int. Agrophysics, 18, 363-368.

WRB, 2006. World Resources Base. FAO, Rome, Italy.

Yukselen-Aksoy Y. and Kaya A., 2010. Method dependency of relationships between specific surface area and soil physicochemical properties. Applied Clay Sci., 50, 182-190. 